\title{
Effects of Changes in Irrigation and Land Use on Streamflow in the Revuelto Creek Watershed, a Tributary of the Canadian River in New Mexico, USA
}

\author{
David Brauer $^{1 *}$ and Dennis Gitz ${ }^{2}$ \\ ${ }^{1}$ Conservation and Production Research Laboratory-ARS-USDA, 2300 Experiment Station Drive, Bushland TX 79012, \\ USA, ${ }^{2}$ Cropping Systems Research Laboratory-ARS-USDA, $38104^{\text {th }}$ Street, Lubbock TX 79401, USA
}

\begin{abstract}
Extensive development in the Canadian River watershed in New Mexico and Texas occurred in the $20^{\text {th }}$ century to supply water for irrigation, and municipal and industrial uses. In recent years (2000-2009), these infrastructures have not been able to supply sufficient water to meet demands. The objective of this study was to assess the effects of changes in irrigation allotments and land use to the Arch Hurley Conservancy District on streamflow out of Revuelto Creek, a tributary of the Canadian River in eastern New Mexico, USA. Outflow from Revuelto Creek varied considerably from 1961 to 2009. The best predictor of annual outflow was a two-component linear model with terms for annual precipitation and the annual irrigation allotment to the Arch Hurley Conservancy District. ArcSWAT (GIS extension of the Soil Water Assessment Tool) simulated outflow from Revuelto Creek best when historical values for irrigation allotments were used in the management operations for cropland. These results indicate that annual irrigation allotments of approximately $123,000,000 \mathrm{~m}^{3}$ increased outflow from the creek by approximately $25,000,000 \mathrm{~m}^{3}$. Years in which the irrigation allotments to the district exceeded $100,000,000 \mathrm{~m}^{3}$ corresponded to years in which water was released from Ute Lake. These results suggest that managers of Lake Meredith need to take into account water availability upstream of Ute Dam when devising plans for Lake Meredith.
\end{abstract}

Keywords: Soil water modeling, irrigation, lateral flow, runoff, semi-arid.

\section{INTRODUCTION}

The Canadian River is the largest tributary of the Arkansas River in the United States, flows approximately $1500 \mathrm{~km}$ from Colorado to eastern Oklahoma and has a watershed of over $122,000 \mathrm{~km}^{2}$. Starting early in the $20^{\text {th }}$ century, the flow of the Canadian River watershed has been managed through dams and diversions as a water source for both agricultural and municipal uses in New Mexico and Texas. Eagle Nest Lake, an impoundment on the Cimarron River, a tributary of the Canadian River, was the first major dam to be constructed in the watershed in New Mexico and Texas when it was completed in 1918 (Fig. 1), and its original purpose was to supply irrigation water for area ranchers. The next dam to be completed in 1939 was Conchas Dam near Conchas, New Mexico, about $50 \mathrm{~km}$ downstream of the confluence of the Cimarron and Canadian Rivers (Fig. 1). In 1954, Bureau of Reclamation completed the construction of channels and control structures (Fig. 1) to transport water from Conchas Dam to farmland near Tucumcari, New Mexico, approximately $80 \mathrm{~km}$ east of Conchas and management of the irrigation project was assumed by Arch Hurley Conservancy Districit (AHCD). Since then, water from Conchas Lake has been used to irrigate a maximum of 17,000 ha of cropland.

*Address correspondence to this author at the Conservation and Production Research Laboratory-ARS-USDA, PO Drawer 10, 2300 Experiment Station Drive, Bushland TX 79012 USA; Tel: 806-356-5769; Fax: 806-356-5750; E-mail: david.brauer@ars.usda.gov
Water available annually to AHCD is determined by the U.S. Army Corp of Engineers based on amount of the water in storage in Conchas Lake and anticipated inflow based on estimates of snow melt and precipitation forecasts $[1,2]$. The amount of water available annually to AHCD has varied over time from 0 to greater than $120,000,000 \mathrm{~m}^{3}[1,2]$. Some of the area supplied with irrigation water by AHCD drains into Ute Lake, while the majority of the irrigated area is in the Revuelto Creek (RC) watershed (Fig. 2). RC flows into the Canadian River below Ute Lake. The primary land cover within the RC watershed is rangeland (Fig. 2).

The Canadian River Compact that was adopted in 1950 limited further development of impoundments in the Canadian River watershed [3]. The compact stated that New Mexico had unrestricted use of all waters originating above Conchas Dam and was authorized to create an impoundment or series of impoundments below Conchas Dam with maximum aggregated storage of $246,000,000 \mathrm{~m}^{3}$. The State of New Mexico used its right in the compact to construct Ute Lake (Fig. 1) beginning in 1962 [4]. Ute Lake and its surrounding area have been incorporated into a state park and recreation is the primary use of the lake. In the future, up to 20,000,000 $\mathrm{m}^{3}$ from Ute Lake will be used as water supply for towns in eastern New Mexico [5].

Texas utilized its right under the Canadian River Compact to construct Lake Meredith, which was designed, built and completed in 1964 by the Bureau of Reclamation. Canadian River Municipal Water Association since 1965 has 


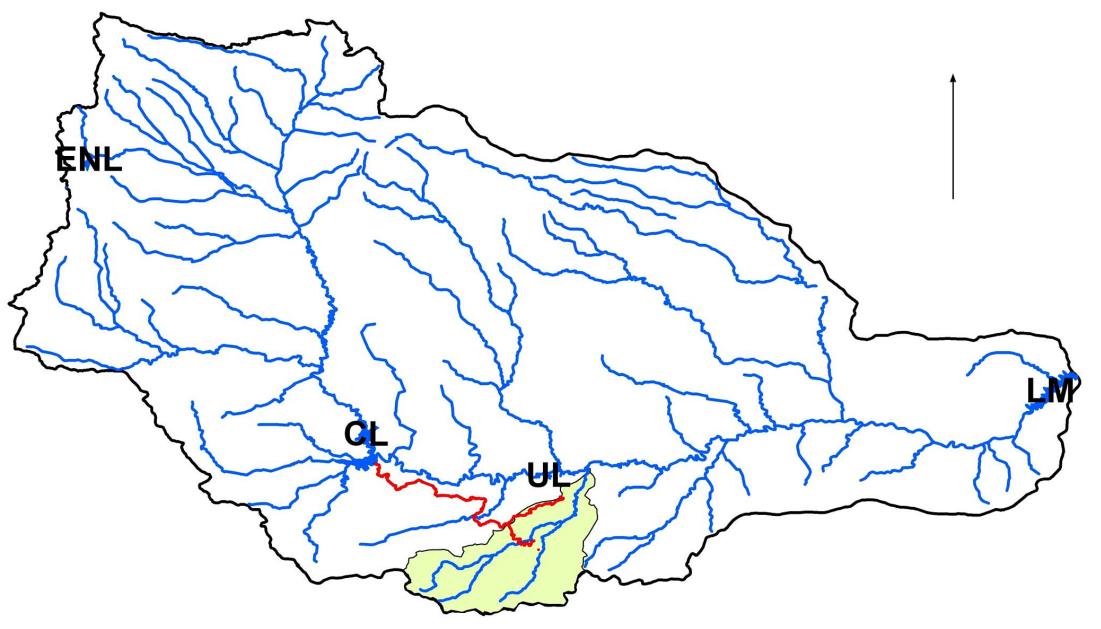

Fig. (1). Canadian River Watershed in Texas and New Mexico upstream of Lake Meredith. The boundary of the Canadian River watershed is depicted by a dark grey line. The Revuelto Creek hydrologic unit depicted as tan shading. The major tributaries and the Canadian River are depicted as blue lines. Locations of the four major reservoirs are identified as such: ENL, Eagle Nest Lake; CL, Conchas Lake; UL, Ute Lake; and LM, Lake Meredith. The major channels of the Arch Hurley Conservancy District are depicted as red lines. The arrow depicts north. The northern and southern edges of the surrounding rectangle represent latitudes of $37.5 \mathrm{o}$ and $34.5 \mathrm{o}$, respectively. The eastern and western edges of the surrounding rectangle depict longitudes of $-101.3 \mathrm{o}$ and $-105.9 \mathrm{o}$, respectively.

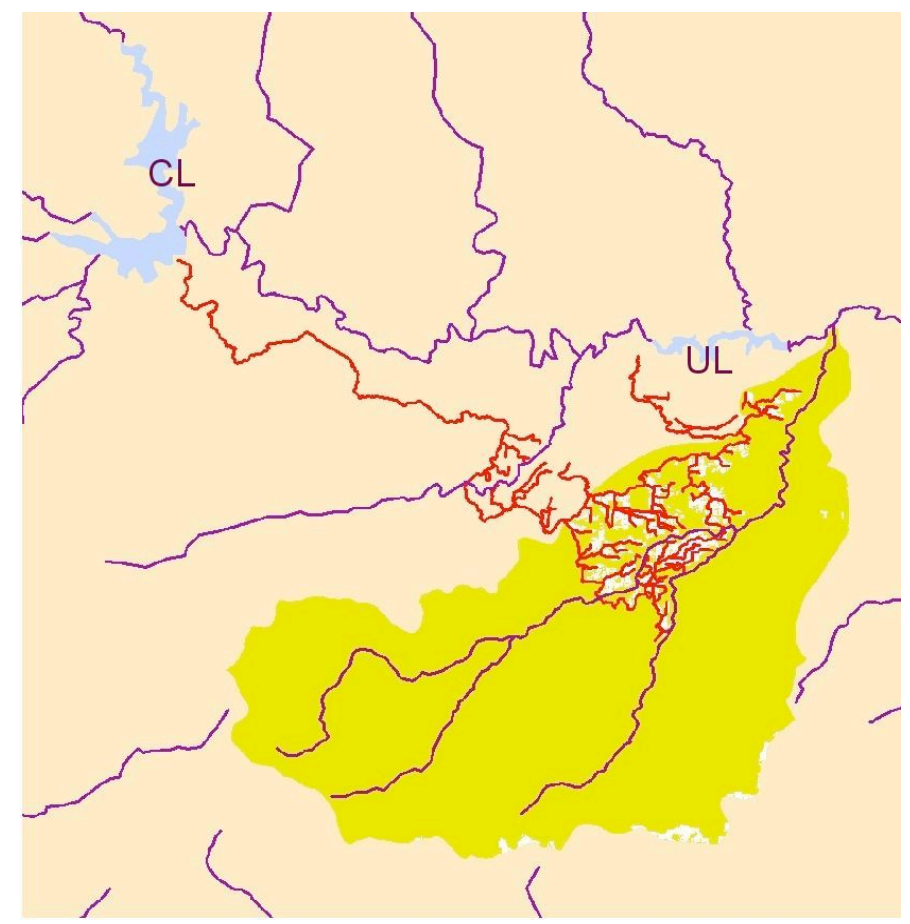

Fig. (2). Location of irrigation channels, cropland and rangeland within the Revuelto Creek watershed. Cropland and rangeland within the Revuelto Creek watershed are depicted in white and greenish-yellow, respectively, and their locations are based data from the 2001 National Land Cover Dataset. Areas outside of the Revuelto Creek watershed are depicted in tan. Creeks and rivers are depicted as dark blue lines. Irrigation channels of the Arch Hurley Conservancy District are depicted as red lines. Conchas Lake and Ute Lake are depicted in light blue and are identified by the abbreviations CL and UL, respectively.

managed water from Lake Meredith and the Ogallala Aquifer to supply 11 cities and towns on the Texas High Plains. It was intended that Lake Meredith would reliably supply over $120,000,000 \mathrm{~m}^{3}$ of water annually. Lake Meredith supplied on average $80,000,000 \mathrm{~m}^{3}$ of water for municipal uses during the 1990's, but deliveries declined throughout the 2000's reaching a low of less than 9,000,000 $\mathrm{m}^{3}$ during 2011 because of low water volume in storage in the reservoir [6]. Low water storage in Lake Meredith is not fully understood. Several studies have been commissioned to determine rea- 
sons for reduced streamflow in the Canadian River between Ute Lake and Lake Meredith, and concomitant storage in Lake Meredith. All of these studies have focused on changes in the watershed between Ute Lake and Lake Meredith, and ignored possible water input from AHCD.

The Soil Water Assessment Tool (SWAT) was developed to model the impact of changes in land use practices on hydrologic processes and the fate of agricultural chemicals in large watersheds [7]. After the development of SWAT, the model was modified into an ArcGIS-ArcView extension and interface, called ArcSWAT. The capabilities of ArcSWAT have been expanded over time including the development of an algorithm to schedule farming operations including irrigation during the simulations. ArcSWAT has successfully simulated the effects of irrigation demand and supply on hydrologic processes in several watersheds differing in geography, climate, soils and crops [8, 9]. Therefore, ArcSWAT appears to be a tool to investigate the effects of changes in land use and irrigation operations on the hydrologic processes of a watershed. The objectives of this study were to: 1) document changes in streamflow out of RC watershed; 2) determine the association between water supply to AHCD and streamflow out of RC watershed; and 3) determine if ArcSWAT can accurately account for changes in streamflow with changes in land use and irrigation allotments.

\section{MATERIALS AND METHODOLOGY}

\section{Data Collection}

Daily mean streamflow data for RC (gage 07227100) were obtained from the U.S. Geological Survey website [10]. This gage is located at N35.3444 and W103.3896 and approximately 200,000 ha contribute to the drainage area measured at the gage. The gage is located approximately 2 $\mathrm{km}$ from the confluence of $\mathrm{RC}$ and the Canadian River. As such, more $99.9 \%$ of the drainage area of the $\mathrm{RC}$ watershed is upstream of the gage. Daily mean flows in cubic feet per second (cfs) were summed within each year and reported herein after being converted to $\mathrm{m}^{3}$ per year. Daily precipitation (PRCP) data were downloaded from the National Climate Data Center [11] and aggregated into monthly or annual sums from three weather stations (Tucumcari, San Jon, and Ragland, New Mexico) located near or within the RC watershed.

Shapefiles of the hydrologic units of the Canadian River from its headwaters to Lake Meredith and the river's major tributaries including RC were downloaded from the US Department of Interior [12]. Land cover data from 2006, 2001, 1992 and 1980 were downloaded from Multi-Resolution Land Characteristics Consortium [13]. The land cover datasets from 2001 and 2006 were derived from several satellite images collected between early spring and late fall of the calendar year of the dataset [14-16]. The land cover datasets for 1980 and 1992 were derived from multiple satellite images collected from 1979 to 1981 , and 1990 to 1992 , respectively $[17,18]$. Land cover raster cells were clipped to the RC watershed using the appropriate hydrologic unit shapefile. Each raster cell was re-classified into seven land cover classes: urban/developed, rangeland, brushy rangeland, cropland (hay fields plus cropland), barren, water, and wetlands using ArcGIS 9, ArcMap version 9.3 [19] to assess the possibility that land cover changes had occurred from 1980 to 2006. Authors of the National Land Cover Database
(NLCD) warned against comparing land cover changes from 1992 and 2001 because of differences in the methodology and land cover classes among these products $[14,15]$. Therefore, to confirm possible changes in land cover between 1999 and 2006, the retrofit land cover products from 2006 and 2001 were downloaded [13] and analyzed using ArcMap by a similar protocol.

Data from the agricultural census for Quay County, New Mexico were obtained from NASS-USDA [20]. The entire RC watershed is within Quay County; however, there is a substantial portion of Quay County that is outside of the RC watershed.

\section{ArcSWAT Simulations}

ArcSWAT [7] was used to simulate the effects of changes in land cover and water available for irrigation on streamflow out of the RC watershed. The specific version of ArcSWAT used in this study was ArcSWAT 2005, version 2009.93.3 beta, released January 27, 2010, version number 414 [21]. Digital elevation maps (DEM) for Quay County, New Mexico were obtained from the NRCS Geospatial Data Gateway [22]. A shapefile of a rectangular mask encompassed the entire RC hydrologic unit and $80 \mathrm{~km}$ buffer area was created in ArcMap. Both NLCD 2001 land cover map for Region 7 and Quay County DEM were clipped to the rectangular mask and projected as Albers Equal Conical Areas. Land cover was classified as urban, cropland, mixed rangeland, herbaceous rangeland, or mixed forest. The STATSGO soils raster file from the ArcSWAT database was also clipped and projected as Albers Equal Conical Areas. These three files were inputs for ArcSWAT. The DEM-based routine was used to determine the stream locations and the shape of the watershed. The watershed was divided into nine sub-basins. The resulting stream reaches and watershed boundaries approximated those obtained from the U.S. Geological Survey (data not shown).

During the delineation of hydrological response units (HRU) in ArcSWAT, land cover category for urban was defined as urban, medium to low density. Cropland was subdivided to be $50 \%$ generic row crops and $50 \%$ hay fields. The division of the cropland into these categories was based on National Agricultural Census data from 1997 and 2002 [20]. Slopes were classified into three categories, $<1 \%, 1-3 \%$ and $>3 \%$. Limits of $10 \%$ for slope and soils were used for the final HUR assignments. This delineation procedure resulted in $280 \mathrm{HRU}$. This protocol resulted in the maximum number of ha being assigned to cropland category and approximated cropland ha in the 2001 and 2006 NLCD (data not shown).

Four of the nine sub-basins had cropland receiving irrigation from the AHCD. For these basins, the management operations for generic row crops were amended as follows. For the period from 1991 to 1998 , a manual irrigation regime was incorporated into both the hay and generic row crop operations to provide $500 \mathrm{~mm}$ of irrigation water from a source outside of the watershed with a uniform distribution over the growing season. For the period from 2001 to 2008, no irrigation was incorporated into the generic row crop management operations. For this later period, the hay operation was modified to provide two irrigation events, totaling $100 \mathrm{~mm}$. These irrigation allotments were based on the mean annual irrigation allotment available to $\operatorname{AHCD}[1,2]$. The rationale for allotting the irrigation water to hay fields in 
Table 1. Correlation of annual Precipitation Among Three Weather Stations Located Near or in the Revuelto Creek Watershed from 1961 to 2009

\begin{tabular}{|c|c|c|c|}
\hline \multirow{2}{*}{ Weather Station } & San Jon & Tucumcari & Ragland \\
\cline { 2 - 4 } & \multicolumn{3}{|c|}{ R-square } \\
\hline \hline San Jon & 1.000 & $0.678^{* * *}$ & $0.807^{* * *}$ \\
\hline Tuc & & 1.000 & $0.734^{* * *}$ \\
\hline Ragland & & & 1.000 \\
\hline
\end{tabular}

*** denotes that the $\mathrm{R}$-square has $\mathrm{P}<0.001$

2001 to 2008 was: farmers would choose to support their investment in a perennial crop prior to incurring expenses for annual row crop production. Daily PRCP data from three weather stations (Tucumcari, San Jon and Ragland) were used as inputs to ArcSWAT. Other weather parameters were simulated using the data in the ArcSWAT weather database. Simulations were run with a three-year warm-up period (no output) and a five-year test period. Output was in terms of monthly water budget and streamflow.
Correlation coefficients among variables and regression equations among dependent and independent variables and the equation's associated R-squares, adjusted R-squares, and Fvalues were determined using PROC CORR and REG [23].

\section{RESULTS}

\section{Streamflow of Revuelto Creek from 1961 to 2009}

Long term weather data are available from three stations in or immediately adjacent to the RC watershed: Ragland, San Jon and Tucumcari. When the values for total annual PRCP from each station were regressed against the other, Rsquares for the regression equations varied from 0.678 to 0.807 (Table 1). These results indicated that total annual PRCP data from each station were indicative of the results from the other two. Therefore, further analyses used the mean total annual PRCP from the three stations.

Total annual PRCP in the RC watershed averaged approximately $947,000,000 \mathrm{~m}^{3}$ from 1961 to 2009 , and varied from a low of approximately $678,000,000 \mathrm{~m}^{3}$ in 1964 to a high exceeding 1,400,000,000 $\mathrm{m}^{3}$ in 1991 (Fig 3A). A sustained period of below average total annual rainfall occurred
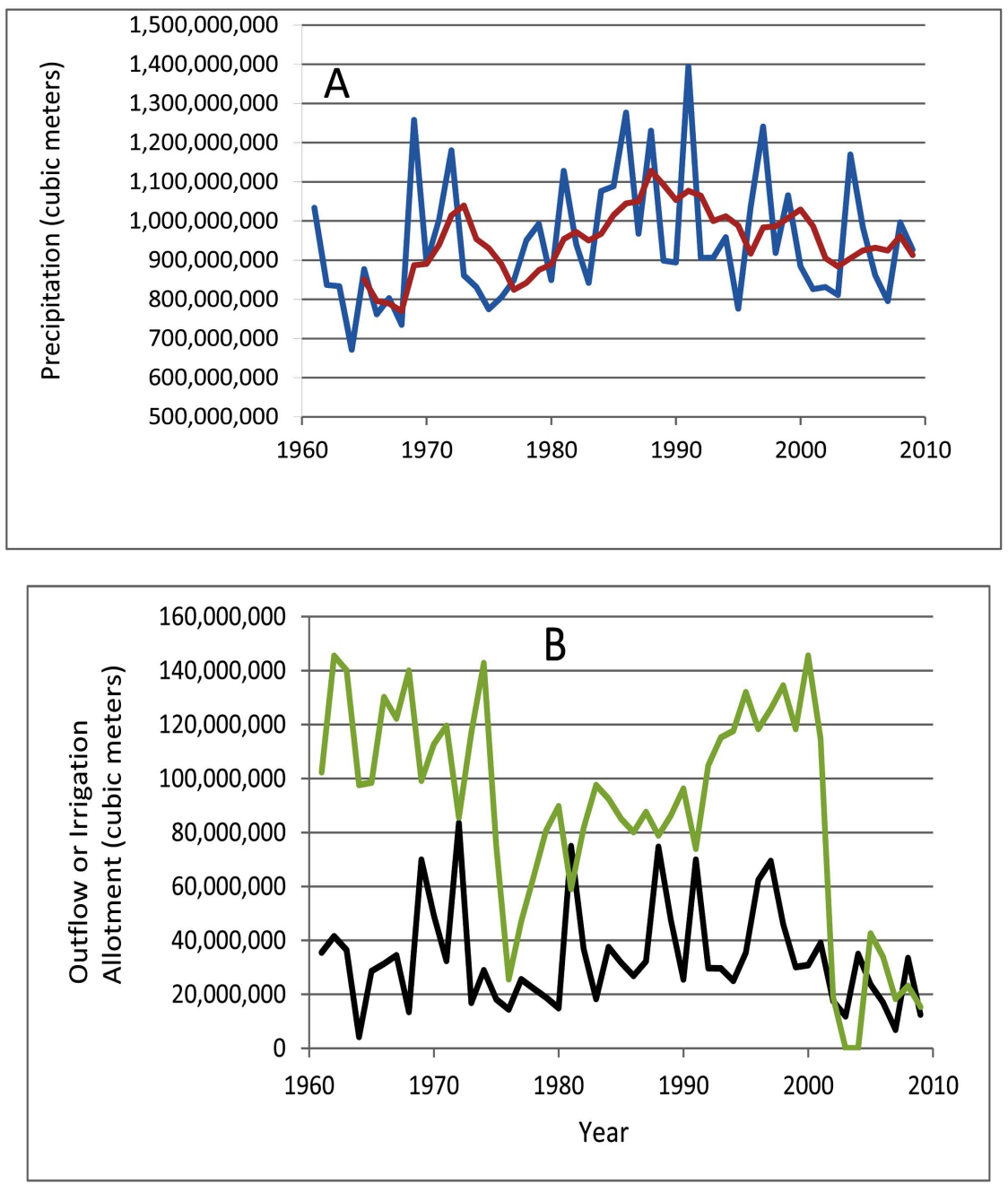

Fig. (3). Precipitation, irrigation allotment to Arch Hurley Conservancy District and streamflow for the Revuelto Creek watershed. Data are from 1961 to 2009. Annual total precipitation for the watershed was calculated from the mean precipitation from three weather stations either in or near the watershed (Panel A, blue). The five-year running means for annual precipitation are also presented (Panel A, red). Annual streamflow was calculated from summing the daily mean flows (Panel B, black line). Annual irrigation allotment from the Arch Hurley Conservancy District appears as the green line in Panel B. 
Table 2. Ability of Annual Precipitation (PRCP), Irrigation Allotments (Irr) and Their Sum to Predict Annual Outflow from Revuelto Creek

\begin{tabular}{|l|c|c|}
\hline \multicolumn{1}{|c|}{ Regression Equation } & \multicolumn{2}{c|}{ Goodness of Fit Parameter } \\
\cline { 2 - 3 } & F-Value & Adjusted R-Square \\
\hline \hline Outflow $\left(\mathrm{m}^{3}\right)=-446,125+0.0826(\mathrm{PRCP})$ & $44.47^{* * *}$ & 0.486 \\
\hline Outflow $\left(\mathrm{m}^{3}\right)=2,369,209+0.1135(\mathrm{Irr})$ & $3.0+$ & 0.059 \\
\hline Outflow $\left(\mathrm{m}^{3}\right)=-470,623+0.0892($ sum PRCP and Irr) & $62.74 * * *$ & 0.522 \\
\hline Outflow $\left(\mathrm{m}^{3}\right)=-620,800+0.0869(\mathrm{PRCP})+0.152(\mathrm{Irr})$ & $33.91^{* * *}$ & 0.591 \\
\hline,$+ * * *$ Denotes significance at $\mathrm{P}<0.1$ and $\mathrm{P}<0.001$, respectively & & \\
\hline
\end{tabular}

in the 1960's and 1970's as evident by the low values for the 5-year running average (Fig. 3A). PRCP from 2000 to 2009 averaged $923,000,000 \mathrm{~m}^{3}$ compared to the long-term mean of $947,000,000 \mathrm{~m}^{3}$.

Amount of water made available by AHCD for irrigation averaged approximately $88,800,000 \mathrm{~m}^{3}$ from 1961 to 2009 (Fig. 3B), but varied considerably during this time period. Since some of the lands receiving water from the AHCD are outside of the RC watershed (Fig. 2), not all of this allotment is an input to the watershed. Available irrigation water exceeded the mean from 1961 to 1974 when the allotment averaged nearly $118,440,000 \mathrm{~m}^{3}$ annually, and from 1992 to 2001 when the amount averaged 123,400,000 $\mathrm{m}^{3}$. Availability of irrigation water was low for two time periods: 1) Irrigation allotment averaged 58,000,000 $\mathrm{m}^{3}$ from 1975 to 1979 with the lowest annual allotment of less than $26,000,000 \mathrm{~m}^{3}$ occurring in 1976; 2) Irrigation allotment to AHCD averaged only $18,500,000 \mathrm{~m}^{3}$ between 2002 and 2009 with no water available for irrigation in 2003 and 2004. Low irrigation allotments to AHCD between 2002 and 2009 were attributed to low water storage in Conchas Lake $[1,2]$. Annual total outflow averaged $33,300,000 \mathrm{~m}^{3}$ over the 48 years. Thus, the average outflow represents approximately $3.5 \%$ of the total annual PRCP. Low streamflow in 1964 was associated with low annual PRCP and lower irrigation. Low rainfall and low available irrigation allotments during the early 1970's was also associated with lower than average streamflow from 1975 to 1979 , when streamflow averaged only slightly less than $20,000,000 \mathrm{~m}^{3}$. Streamflow from 2002 to 2009 also was below the long-term average with a mean flow of 19,700,000 $\mathrm{m}^{3}$. The 2002-2009 time period was associated with low allotments for irrigation but total annual PRCP was near the average stated above. An inspection of the data in Fig. (3A and 3B) suggested that years of low streamflow out of RC watershed were associated with low total annual PRCP and/or low irrigation allotments.

The relationships between streamflow out from RC watershed and total annual PRCP and irrigation allotments were explored in greater depth using regression analyses. Rsquares among annual values for total PRCP, irrigation allotment, the mathematical mean of annual irrigation allotment and annual PRCP and outflow from RC were determined. Regression equations to predict outflow (dependent variable) were highly significant (Table 2) when the independent variable was either total annual PRCP (R-square = $0.486, \mathrm{P}<0.001)$ or the sum of the annual irrigation allotment and PRCP (R-square $=0.526, \mathrm{P}<0.001)$. There was a slight tendency for outflow to be associated with the annual irrigation allotment $(\mathrm{R}$-square $=0.059, \mathrm{P}=0.088)$. The sum of irrigation allotment and PRCP was highly correlated with the annual PRCP $(\mathrm{R}$-square $=0.937, \mathrm{P}<0.001)$ but not with the annual irrigation allotment $(\mathrm{R}$-square $=0.020, \mathrm{P}>0.10$ level).

The equation with the highest R-square was a linear model including two terms, one for annual PRCP and the other for the annual irrigation allotment (Table 2). Backward elimination regression analyses to predict outflow (dependent variable) starting with independent variables of total annual PRCP, annual irrigation allotment, and sum of PRCP and irrigation allotment resulted in a two component model consisting of irrigation allotment and total PRCP. One reason for the greater R-square for the two-term model may be that the slopes for PRCP and irrigation allotment were significantly different. These results support the visual trends in Fig. (3), that is, low streamflow from the RC watershed was associated with both low total annual PRCP and irrigation allotments.

\section{Changes in Land Cover 1980 to 2006}

Between 1980 and 2006, rangeland has been the dominant land cover in the RC watershed (Table 3). Mixed and herbaceous rangeland occupied approximately 170,000 ha in 1980 and increased between 1980 and 2001 to approximately 196,000 ha. The distribution between mixed and herbaceous rangeland changed dramatically between the 1980 and 1992 databases. In 1980, mixed rangeland was the dominant land cover as compared with herbaceous rangeland in 1992. There was no retrofit product to compare the 1980 and 1992 database; therefore, it is not known if this shift between the two rangeland classes reflects a change in land cover or a change in methodology to prepare the land cover data bases. The retrofit product comparing the 1992 and 2001 land cover database does not discriminate between the two type of rangeland; so conclusions regarding the increase in mixed rangeland between 1992 and 2001 are speculative. The 1980 NLCD database indicates a relatively high coverage by forest, approximately 20,000 ha (Table 3). The soil survey created in the 1970's does not mention any significant forested areas occurring in the studied area [24]. Therefore, the relative high number of ha assigned to forest land cover in 1980 may reflect an inability to differentiate mixed rangeland from the forest cover class in the study area.

The NLCD databases from 1980 to 2001 indicate that the cropland area which includes row crops and hayfields [13], declined from 20,285 ha in 1981 to 10,447 ha in 2001 
Table 3. Changes in Land Cover from 1980 to 2006. Land Cover Products from the National Land Cover Database were Analyzed by ArcMap. Land Cover Classes of the 1992 to 2006 Products were Converted to that of the 1980 Database

\begin{tabular}{|c|c|c|c|c|}
\hline \multirow{3}{*}{ Land Cover Class } & \multicolumn{4}{|c|}{ Year } \\
\hline & 1980 & 1992 & 2001 & 2006 \\
\hline & \multicolumn{4}{|c|}{ hectacres } \\
\hline Developed / Urban & 640 & 120 & 2,149 & 2,645 \\
\hline Cropland (row crop plus hayfields) & 20,285 & 18,000 & 10,447 & 9,857 \\
\hline Herbaceous rangeland & 11,243 & 161,645 & 117,842 & 117,463 \\
\hline Total rangeland & 169,988 & 190,041 & 196,549 & 196,646 \\
\hline Forest & 20,008 & 620 & 1,193 & 1,193 \\
\hline Water & 0 & 66 & 147 & 141 \\
\hline Wetlands & 79 & 0 & 620 & 1,112 \\
\hline
\end{tabular}

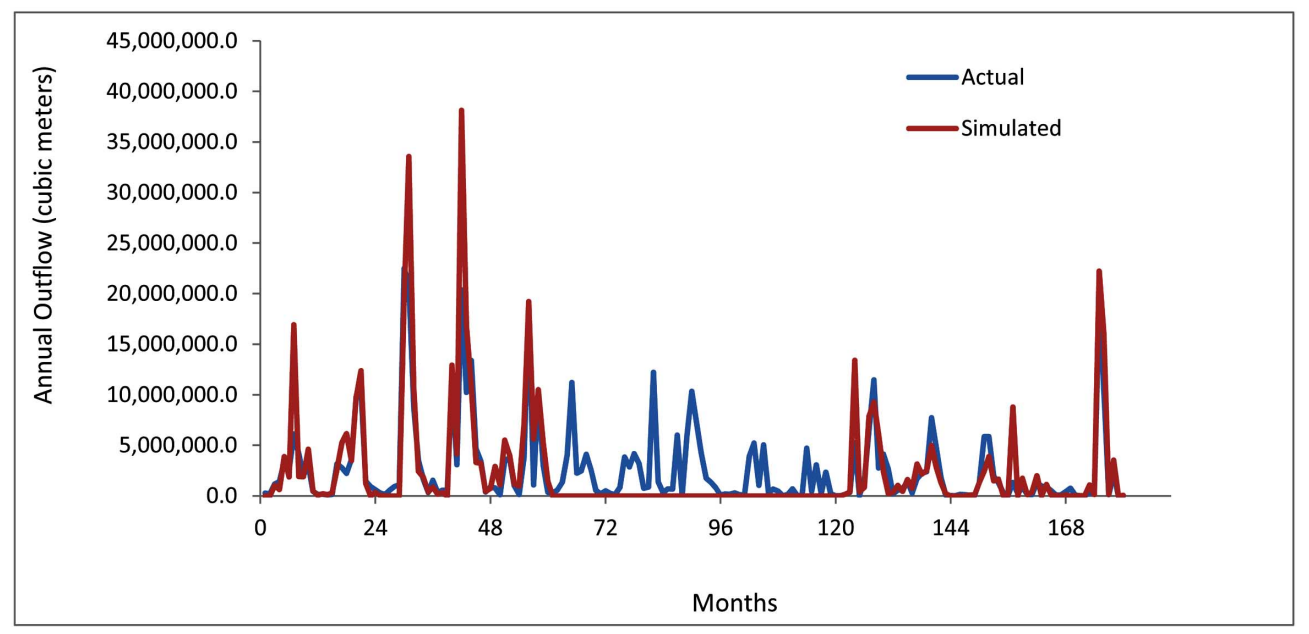

Fig. (4). Comparison of the monthly outflow from Revuelto Creek to that predicted by ArcSWAT. The first month in the dataset is January 1994, the beginning of the first of two ArcSWAT simulations. Actual monthly outflow was computed from summing of daily mean outflow (blue line). Simulated data are the red line. The ArcSWAT simulations from 1994 to 1998 included 500 mm of irrigation water being applied annually in the Arch Hurley Conservancy District in the watershed. The second simulation from 2004 to 2008 assumed that only half of the acres were receiving water from the conservancy district and the annual allotment was only $100 \mathrm{~mm}$.

(Table 3). A small number of cropland ha was lost between 2001 and 2006. The retrofit products comparing the 1992 and 2001 databases indicated a similar loss in cropland ha (data not shown). The retrofit product comparing the 2001 and 2006 indicated little, if any, change in land cover (data not shown). Spatial analyses of cropland in the 1992, 2001 and the 1992-2001 retrofit databases indicated that most of the loss in cropland occurred in areas not adjacent to the channels of the AHCD (data not shown) and thus presumably were sites of dryland row crops.

Data from the agricultural census for Quay County, New Mexico from 1987 to 2007 tend to confirm the trends from the NLCD databases. Irrigated ha in Quay County decreased from 16,558 ha in 1997 to 12,022 and 7,606 ha in 2002 and 2007, respectively [20]. Distribution of crops within the irrigated area also changed over this time period. In 1987, irrigated cropland (7,700 ha) exceeded irrigated alfalfa $(3,700 \mathrm{ha})$ and irrigated other hay crops (2,100 ha). By 2002, irrigated alfalfa acreage (2,700 ha) was half that of irrigated other hayfields $(5,400 \mathrm{ha})$. Therefore, the decreases in water available for irrigation from the AHCD were associated with decreases in irrigated ha and a shift from alfalfa to other hay crops.

\section{ArcSWAT Simulations}

The ability of ArcSWAT to simulate the effects of changes in irrigation allotments to AHCD on outflow from the RC from 1991 to 2008 was chosen because there was a large decrease in water available for irrigation in the watershed during this time period $[1,2]$. The simulation procedures described in the Materials and Methods were able to provide a prediction of outflow from the $\mathrm{RC}$ watershed that was similar to the observed monthly outflows (Fig. 4). The largest departure of actual to simulated values occurred for the greatest monthly outflows that occurred during the 
Table 4. Regression Equations Relating Actual Monthly Outflows from the Revuelto Creek Watershed to Outflows Values Predicted by ArcSWAT

\begin{tabular}{|c|c|c|c|c|}
\hline \multirow{2}{*}{ Years in Simulation } & Irrigation Allotment for Simulations ${ }^{1}$ & \multirow{2}{*}{ Slope } & \multicolumn{2}{|c|}{ Goodness of Fit Parameter } \\
\cline { 3 - 5 } & F-Value & & \multicolumn{2}{|c|}{ R-Square } \\
\hline \hline $1994-1998$ & $500 \mathrm{~mm}$ & 0.677 & 611.6 & 0.838 \\
\hline $2004-2008$ & $100 \mathrm{~mm}^{2}$ & 0.660 & 323.9 & 0.848 \\
\hline $1994-1998$ & $500 \mathrm{~mm}$ & 0.726 & 216.4 & 0.789 \\
\hline $2004-2008$ & $100 \mathrm{~mm}^{2}$ & 0.296 & 0.448 \\
\hline $1994-1998$ & None & 0.964 & 107.8 & 0.631 \\
\hline $2004-2008$ & None & 0.195 & 61.1 & 0.505 \\
\hline
\end{tabular}

${ }^{1}$ Amount of water made available by the Arch Hurley Conservancy District for irrigation annually.

${ }^{2}$ Irrigation allotments so designated are on half of the land area as the other allotment

1990's. When the predicted values from the two simulations based on historical allotments for irrigation were compared to actual flow values, the resulting regression model had Fvalue of $611.6(\mathrm{P}<0.001)$ and $\mathrm{R}$-square of 0.838 (Table 3 ). The Nash-Sutcliffe value [25] was 0.79 comparing observed versus predicted monthly flows in Fig. (4).

Irrigation allotments were varied in other simulations to test the hypothesis that the use of historical values for irrigation allotments would produce the ArcSWAT simulations of stream outflow with the highest R-square and F-value. When no irrigation was included in the simulation for 1994-1998, the F-value and R-square for the regression model between actual and simulated was still highly significant $(\mathrm{P}<0.01)$, but the model's F-value and R-square were substantially less, 47.1 and 0.448 , respectively (Table 4). Deleting the irrigation allotment for the management operations for the simulations including 2004 to 2008 had less an effect on the Fvalue and R-square of the model, 107.8 and 0.631 , respectively. Such a minor change in the predictive power of the model probably reflects the minor input that irrigation from the AHCD had to the watershed's water budget from 2004 to 2008. However, increasing the irrigation allotment to 500 $\mathrm{mm}$ for the 2004 to 2008 time period reduced the predictive power of the regression model between actual and simulated outflows more than removing the irrigation allotment, as evident by the F-value and R-square of 61.1 and 0.505 , respectively. Overall, these results support the hypothesis that the simulations of outflow from RC watershed were best approximated when historical values for the irrigation allotment are included in the ArcSWAT simulation.

ArcSWAT simulations were conducted following the described protocols and historical irrigation allotments for the 1991 to 1999 and 2001 to 2008 time periods except that all the rangeland was assigned to either $100 \%$ brushy rangeland or $100 \%$ herbaceous rangeland. Simulated values for outflow from $\mathrm{RC}$ water under these two extreme characterizations of the rangeland were within $3 \%$ of those when the rangeland was classified according to the 2001 National Land Cover Database (data not shown).

\section{DISCUSSION}

Interest in the RC watershed is twofold. First, RC watershed is a microcosm for important changes that are occurring throughout the Southern High Plains. Water available for irrigation in many places on the Southern High Plains has already declined or will be decreased in the near future due to either decreases in the groundwater storage in the Ogallala Aquifer or changes in water policies. Significant depletion of the groundwater in the Ogallala Aquifer has been noted in various parts of the Southern High Plains including areas in the the states of Colorado, Kansas, New Mexico and Texas [26]. In some areas sufficient depletion has occurred to curtail irrigation. In other parts of Texas, groundwater management districts are establishing restrictions on the amount of groundwater that farmers can withdraw [27]. These restrictions are so that the districts can meet desired future condition for the Ogallala Aquifer that was set by the water planning groups in 2010 [28]. A desired future condition is a target for what a specific aquifer will be 50 years into the future. For a large part of the Ogallala Aquifer in Texas, the desired future condition agreed upon in 2010 was that $50 \%$ of the water storage in 2010 would be remaining in 2060 . Established from this $50 \%$ desired future condition has essentially reduced the supply of water for irrigation in the region by half [28]. How this decrease in irrigation will affect the region's hydrology is not known, but trends from the $\mathrm{RC}$ watershed may be useful since irrigation water availability has declined significantly in the past 20 years. Another trend that is occurring on the Southern High Plains that RC may model is the effects of brush intrusion into short grass prairie on hydrology.

A second reason for examining hydrologic trends in the $\mathrm{RC}$ watershed is its effects on streamflow in the Canadian River watershed downstream of Ute Lake and as a possible source of water for storage in Lake Meredith. As mentioned earlier, Lake Meredith was created as a regional water supply for 11 cities and town on the Texas High Plains; however, due to low water storage, Lake Meredith has supplied only a fraction of the water needed by these municipalities in recent years [6]. Previous studies to determine reasons for reduced streamflow in the Canadian River between Ute Lake and Lake Meredith have not considered changes in hydrology upstream of Ute Lake $[29,30]$. One the objectives of this study was to determine if water withdrawn from Conchas Lake for irrigation in the AHCD contributes to streamflow in the Canadian River watershed below Ute lake.

Streamflow out of the RC watershed has varied greatly from 1961 to 2009 (Fig. 3). Annual outflow was positively 
correlated with the total annual PRCP and with a twocomponent linear model including separate terms for PRCP and the irrigation allotment to AHCD (Table 2). In the twocomponent linear model, the slope between outflow and input was almost twice as great for the irrigation allotment compare with the annual precipitation, 0.087 versus 0.152 . The best correspondence between observed outflow and values simulated by ArcSWAT occurred when historical values for the irrigation allotment were incorporated into the management operations for the cropped land (Table 4). These results indicated that outflow from the $\mathrm{RC}$ watershed was positively associated with total annual PRCP and allotments to the AHCD irrigation project. These results suggest that decreases in streamflow may occur throughout the Southern High Plains as less irrigation water is applied in the future.

Little change in simulated outflow from RC watershed occurred with changes in the assignment of rangeland to various sub-categories of rangeland. These results suggested that invasion of brush into the rangeland has little effect on the amount of water transferred to the creek. Brush invasion into rangeland had been suspected as a cause for decreased water flow into the Canadian River between Ute Lake and Lake Meredith [29, 30]. However, Rainwater et al. [31] concluded that invasion of rangeland by upland brushy vegetation probably had little effect on runoff or infiltration of rainfall beyond the rooting depth of plants. The results in this report do not support the hypothesis that brush intrusion into the rangeland has been responsible for lower river flows. These analyses do not pre-occlude the possibility that brushy tree species, like salt cedar (Tamarix species), growing immediately adjacent to the waterway decrease water in the streambed in between rain events and that more rain or runoff was needed to fill these depressions before streamflow attains a minimum value.

These results have implications regarding streamflow in the Canadian River downstream of Ute Lake and ultimately as storage in Lake Meredith. In years when the irrigation allotments to ACHD exceeded 120,000,00 $\mathrm{m}^{3}$, like from 1991 to 1998 , the annual outflow from RC averaged almost $46,000,000 \mathrm{~m}^{3}$ compared to $23,000,000 \mathrm{~m}^{3}$ from 2001 to 2008 when the irrigation allotments were substantially less. This suggests that irrigation water from Conchas Lake allotted to the AHCD provided on average approximately $23,000,000 \mathrm{~m}^{3}$ to the Canadian River downstream of Ute Lake and upstream of Lake Meredith. There was also a positive association between years with allotments to ACHD exceeding $120,000,000 \mathrm{~m}^{3}$ and releases from Ute Lake into the Canadian River (data not shown). For example, annual flow at the US Geological Survey gage on the Canadian River at Logan, New Mexico averaged approximately $30,000,000 \mathrm{~m}^{3}$ from 1991 to 1998 compared to a mean of only $4,000,000 \mathrm{~m}^{3}$ from 2001 to 2008 . The gage near Logan, New Mexico is just downstream of Ute Lake and primarily represents releases from that impoundment. Therefore, flow in the Canadian River downstream of the confluence with RC was approximately 50 million $\mathrm{m}^{3}$ greater in the 1990 's than in the 2000's.

\section{CONCLUSION}

The results in this study indicated that changes in irrigation volume applied had a greater effect on streamflow in $\mathrm{RC}$ watershed than conversion of grassland to brushy rangeland. These results also suggest that flow of the Canadian River into Texas is more likely to be greater in those years when more water is available in the watershed above Ute Lake, due to direct releases from Ute Dam and indirectly from the movement of irrigation water on cropland in the AHCD into $\mathrm{RC}$ and then in turn into the Canadian River below Ute Dam. These results also indicate that water planners and managers of Lake Meredith need to account for changes in hydrology in the Canadian River watershed upstream of Ute Lake, in addition to changes in the watershed between Ute Lake and Lake Meredith.

\section{CONFLICT OF INTEREST}

The authors confirm that this article content has no conflicts of interest.

\section{ACKNOWLEDGEMENTS}

The U.S. Department of Agriculture (USDA) prohibits discrimination in all its programs and activities on the basis of race, color, national origin, age, disability, and where applicable, sex, marital status, familial status, parental status, religion, sexual orientation, genetic information, political beliefs, reprisal, or because all or part of an individual's income is derived from any public assistance program. (Not all prohibited bases apply to all programs.) Persons with disabilities who require alternative means for communication of program information (Braille, large print, audiotape, etc.) should contact USDA's TARGET Center at (202) 720-2600 (voice and TDD). To file a complaint of discrimination, write to USDA, Director, Office of Civil Rights, 1400 Independence Avenue, S.W., Washington, D.C. 20250-9410, or call (800) 795-3272 (voice) or (202) 720-6382 (TDD). USDA is an equal opportunity provider and employer.

The use of trade, firm, or corporation names in this web site is for the information and convenience of the reader. Such use does not constitute an official endorsement or approval by the United States Department of Agriculture or the Agricultural Research Service of any product or service to the exclusion of others that may be suitable.

This research was supported by the Ogallala Aquifer Program, a research and education consortium consisting of ARS-USDA, Kansas State University, Texas AgriLife/ TAMU, Texas Tech University and West Texas A\&M University.

\section{REFERENCES}

[1] Arch Hurley Conservancy District. Board Minutes: 2008-2011 2012. Available from URL: http://archhurley.com/?page_id=13 Verified on March 31, 2012.

[2] King JP, Hawley JW, Hernandez J, Kennedy JF, Martinez EL. Study of potential water salvage on the Tucumcari Project, Arch Hurley Conservancy District. New Mexico Water Resources Institute, New Mexico State University, Report TR335. 2006. Available from URL: http://wrri.nmsu.edu/publish/techrpt/abstracts/abs 335.html. Verified May 7, 2012.

[3] Bliss JH, Spence EV, Burch C. Canadian River Compact. 1950. Available from URL: http://wrri.nmsu.edu/wrdis/compacts/Canadian-River-Compact.pdf. Verified on March 312012.

[4] US Army Corps of Engineers. National Inventory of Dams. 2009. Available from URL: http://geo.usace.army.mil/pgis/f?p=39$: 1: 931219916894442$. Verified March 31 2011. Access to data is limited by permission from the webmaster. 
[5] Eastern New Mexico Rural Water System. Eastern New Mexico Rural Water System: Home. 2011. Available from URL: http://www.enmrwa.com/default.htm. Verified on April 12011.

[6] Canadian River Municipal Water Authority. CRMWA: Water supply/allocations 1965-2011. 2011. Available from URL: http://www.crmwa.com/Downloads/2011\%20City\%20Allocations \%20Schedule.pdf Verified on May 7, 2012.

[7] Arnold JG, Srinivasan R, Muttiah RS, Williams JR. Large area hydrologic modeling and assessment, Part I: Model development. J Am Water Resour Assoc 1998; 34: 73-89.

[8] Santhi C, Muttiah RS, Arnold JG, Srinivasan R. A GIS-based regional planning tool for irigation demand assessment and savings using SWAT. Trans ASAE 2005; 48: 137-47.

[9] Zheng J, Li G, Zhen-zhong H, Meng G. Hydrologic cycle simulation of an irrigation district based on a SWAT model. Math Comput Modeling 2010; 51: 1312-8.

[10] US Geological Survey. USGS Real-Time Water Data for the Nation. 2012. Available from URL: http://waterdata.usgs.gov/nwis/rt. Verified on March 31, 2011.

[11] National Climate Data Center. NNDC Climate Data Online: Station Name Search. 2012. Available from URL: http://cdo.ncdc.noaa.gov/cgi-bin/cdo/cdostnsearch.pl. Verified July 12, 2011.

[12] US Department of Interior. National Atlas of the United States: Water of the United States. 2010. Available from URL: http://nationalatlas.gov/water.html Verified July 12, 2011.

[13] Multi-Resolution Land Characteristics Consortium. National Land Cover Database. 2010. Available from URL: http://www.mrlc.gov/index.php. Verified July 12, 2011.

[14] Homer C, Huang C, Yang L, Wylle B, Coan M. Development of a 2001 national land-cover database for the United States. Photogramm Eng Remote Sens 2004; 70: 829-40.

[15] Xian G, Homer C, Fry J. Updating the 2001 National Land Cover Database land cover classification to 2006 by using Landsat imagery change detection methods. Remote Sens Environ 2009; 113: 1133-47.

[16] Fry J, Xian G, Jin S, et al. Completion of the 2006 National land Cover Database for the Conterminous United States. Photogramm Eng Remote Sensing 2011; 77: 858-64.

[17] Loveland TR, Merchant JW, Ohlen DO, Brown JF. Development of a landcover characteristics database for the conterminous U.S. Photogramm Eng Remote Sensing 1991; 57: 1453-63.

[18] Vogelmann JE, Sohl TL, Campbell PV, Shaw DM. Regional land cover characterization using Landsat thematic mapper data and ancillary data sources. Environ Monit Assess 1998; 51: 415-28.

[19] ESRI. ArcGIS 9, ArcMap version 9.3. 2008. ESRI Inc, Redlands, CA, USA.

[20] NASS-USDA The Census of Agriculture. 2009. Available from URL: http://www.agcensus.usda.gov/Verified July 12, 2011.
[21] Neitsch SL, Arnold JG, Kiniry JR, Williams JR. Soil and Water Assessment Tool, Theoretical Documentation: Version 2005. Temple, TX: USDA Agricultural Research Service and Texas A\&M Blackland Research Center 2005.

[22] NRCS-USDA. Geospatial data gateway. 2011. Available from URL: http://datagateway.nrcs.usda.gov/. Verified July 12, 2011.

[23] SAS Institute. The SAS User's Guide, version 9.2. 2002.

[24] Ross WJ, Pease DS. Soil survey of Tucumcari Area, New Mexico, Northern Quay County, 1974. Washington DC: USDA, Soil Conservation Service in cooperation with the New Mexico Agricultural Experiment Station. USDA, USA. pp. 94.

[25] Nash JE, Sutcliffe IV. River flow forecasting through conceptual models; Part I-A discussion of principles. J Hydrol 1970; 10(3): $282-90$

[26] McGuire VL. Water-level changes in the High Plains aquifer, predevelopment to 2007, 2005-06, and 2006-07. U.S. Geological Survey Scientific Investigations Report 2009-5019. 2009. Available from URL: http://pubs.usgs.gov/sir/2009/5019. Verified July $10,2012$.

[27] High Plains Underground Water Conservation District No. 1. Rules of the High Plains Underground Water Conservation District No. 1 as amended February 21, 2012. 2012. Available from URL: http://www.hpwd.com/Downloads/FINAL\%20District\%20Rules\% 20As\%20Amended\%20July\%2019,\%202011/High\%20Plains\%20 Rules\%20Adopted\%20July\%2019\%202011\%20and\%20Civil\%20 Penalty\%20Schedule\%20-\%20Last $\% 20$ Amended $\% 20$ February\%2021\%202012.pdf Verified July 10, 2012.

[28] High Plains Underground Water Conservation District No. 1. Setting desired future conditions for aquifers signals new era of groundwater management. The Cross Section 2009; 55(10); 1-3. Available from URL: http://www.hpwd.com/CrossSection/102009\%20Cross\%20Section.pdf. Verified July 10, 2012.

[29] Spencer S, Salazar A. Historical trends in key components of the hydrologic cycle for the Lake Meredith watershed. Report from Freese and Nichols commissioned by the Panhandle Water Planning group. 2010. Available from URL: http://www.panhandlewater.org/2011_adopted_plan.html or http://www.crmwa.com/Downloads.htm. Verified on March 31, 2011.

[30] Wilson L, O'Brien V. Canadian River watershed: Brush control planning, assessment and feasibility study. 2000. Available from URL: http://www.tsswcb.state.tx.us/files/docs/brush/feasibilitystudies/canadianriver_0.pdf. Verified on March 31, 2011.

[31] Rainwater KA, Fish EB, Zartman RE, Wan CG, Schroeder JL, Burgett WS. Evaluation of the TSSWCB Brush Control Program: Monitoring Needs and Water Yield Enhancement. 2008. Available from URL: http://74.125.155.132/scholar?q=cache:D_p5MeTlqOYJ:scholar.google.com $/ \& \mathrm{hl}=$ en\&as_sdt $=0,5 \&$ as_ylo $=2008 \&$ as_y hi=2011. Verified on July 12, 2011.

\begin{tabular}{lcc}
\hline Received: May 11, 2012 & Revised: July 11, 2012 Accepted: August 03, 2012
\end{tabular}

(C) Brauer and Gitz; Licensee Bentham Open.

This is an open access article licensed under the terms of the Creative Commons Attribution Non-Commercial License (http://creativecommons.org/licenses/by-nc/3.0/) which permits unrestricted, non-commercial use, distribution and reproduction in any medium, provided the work is properly cited. 